\title{
Ferrocene derivatives of liquid chiral molecules allow for assignment of absolute configuration by X-ray crystallography
}

\author{
Philipp M. Holstein ${ }^{\mathrm{a}, 1, *}$, Julian J. Holstein $^{\mathrm{b}}{ }_{*}$, Eduardo C. Escudero-Adán $^{\mathrm{a}}$, Olivier Baudoin ${ }^{\mathrm{c}}$ and Antonio \\ M. Echavarren ${ }^{\mathrm{a}, \mathrm{d}}$ \\ a Institute of Chemical Research of Catalonia (ICIQ), Barcelona Institute of Science and Technology, Av. Països Catalans 16, 43007, Tarragona, Spain \\ ${ }^{b}$ Faculty of Chemistry and Chemical Biology, TU Dortmund, Otto-Hahn-Str.6,44227 Dortmund, Germany \\ ${ }^{c}$ University of Basel, Department of Chemistry, St. Johanns-Ring 19, CH-4056 Basel, Switzerland

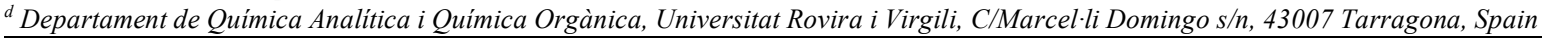

\section{ARTICLE INFO \\ ABSTRACT}

\section{Article history:}

Received

Received in revised form

Accepted

Available online

Keywords:

Keyword_1
The present study investigates a synthetically simple ferrocene derivatization of natural products and active pharmaceutical ingredients. Seven new crystal structures are analyzed together with 16 structures of ferrocene derivatives reported previously. In all cases the unambiguous determination of the absolute structure was established from anomalous dispersion using the methods of Flack and Parsons. A comparison with other derivatization approaches shows the advantage of the herein described ferrocene derivatization for establishing the absolute configuration of novel compounds.

2009 Elsevier Ltd. All rights reserved.

* Corresponding authors. Tel.: +33 437561663 (P.M.H.), Tel.: +49 2317553426 (J.J.H.); fax: +49 2317558138 (J.J.H.); e-mail: pholstein@iciq.es (P.M.Holstein), julian.holstein@tu-dortmund.de (J.J.Holstein).

${ }^{1}$ Present address: Edelris, 115, Av. Lacassagne, 69003 Lyon, France. 


\section{Introduction}

Chirality plays a central role in biological recognition processes. Therefore, the vast majority of molecules addressing biological receptors such as natural products, active pharmaceutical ingredients (APIs) and fragrances are chiral. Asymmetric synthesis and enantioselective total synthesis have seen major advances in the recent past. Unfortunately, we are facing deficits in the analysis of unknown compounds as witnessed by the considerable number of wrongly assigned natural products in the literature. ${ }^{1,2}$ As a consequence, the correction of structural assignments for natural products is a common outcome of total syntheses. Whereas these efforts correct wrongly assigned structures in the literature, it is a very costly way to do so. New methods for better and easier determination of the absolute structure are still necessary. Currently a general approach for the absolute structure determination does not exist ${ }^{3,4}$ and different methods are available among them NMR, ${ }^{5-7}$ chiroptical spectroscopic methods $^{8}$ and X-ray diffraction. ${ }^{5,9}$ When crystals of a molecule of interest can be obtained, single-crystal X-ray crystallography is the method of choice for structure elucidation. ${ }^{9,10}$ It gives access to the three dimensional structure of a molecule and, with the method introduced by Flack, also allows to determine the absolute structure of a crystal on a routine basis. ${ }^{11-14}$ This allows to assign the absolute configuration of the chiral molecules contained in the crystal structure. Hooft ${ }^{15}$ and Parsons ${ }^{16}$ have further optimized this approach which even allows the absolute structure determination of molecules containing only light atoms. ${ }^{17}$

With advances in primary beam intensity, computational power and X-ray detectors, the measurement as well as the refinement have become fast processes, which make crystallography a rapid technique to determine previously unknown molecular structures. However, the way from a pure compound to a suitable single crystal is often tedious and the bottle neck of the process. ${ }^{10}$ Samples which are liquid at room temperature represent a particular challenge. Although crystallization under cryogenic conditions is possible, it requires specialized equipment and takes a considerable effort. Even solid samples can require crystallization to give a single crystal of good quality. ${ }^{18}$ It is therefore not surprising that the discussion about crystal size and quality can lead to incomprehension between crystallographer and synthetic chemist. In some cases special equipment or sophisticated methods can help. Tiny crystals with dimensions below $0.1 \times 0.1 \times 0.1 \mathrm{~mm}$ can nowadays be measured on modern in-house diffractometers and more primary beam intensity is available at modern synchrotron X-ray diffraction beamlines. The group of Fujita has presented the crystalline sponge method, a supramolecular approach which is based on soaking small molecules into MOF crystals. ${ }^{19}$ Its procedure has been critically assessed, ${ }^{20}$ further optimized ${ }^{21}$ and successfully applied for assigning the absolute configuration of natural products. ${ }^{22,23}$ Nevertheless, establishing the absolute configuration of liquid or non-crystalline compounds remains a challenge frequently encountered in the synthetic laboratory. Historically organic chemists solve this problem by derivatization. Before the arrival of powerful spectroscopic methods crystallization and determination of melting points were of central importance as purification and analytic method respectively. From the late $19^{\text {th }}$ century, alcohols were converted into the corresponding nitrobenzoates $\left(4-\mathrm{NO}_{2}\right.$ or $3,5-\left(\mathrm{NO}_{2}\right)_{2}$ benzoates), aldehydes and ketones into the corresponding 3,5$\left(\mathrm{NO}_{2}\right)_{2}$-phenyl hydrazones ${ }^{24,25}$ which are characterized by high crystallinity and sharp melting points. Comparison of the obtained melting points allowed proving the structural identity of products. Milestones such as Emil Fischer's ground breaking work on sugars and the asymmetric carbon atom itself was based on chemical derivatization. ${ }^{26,27}$ The conversion of different sugars into their corresponding osazones ${ }^{28}$ (Scheme 1a) which have sharp melting points and stable optical rotations enabled Emil Fischer's fundamental work with which the concept of the chiral carbon atom was introduced into sugar chemistry. ${ }^{29}$ Also the characterization and the first industrial synthesis ${ }^{30}$ of vitamin A involved esterification into the corresponding anthraquinone ester $4^{31}$ for the purpose of recrystallization (Scheme 1b). ${ }^{32}$ After purification at this stage, saponification liberates the desired vitamin $\mathrm{A}$ in its pure, high melting form. ${ }^{33}$ a)

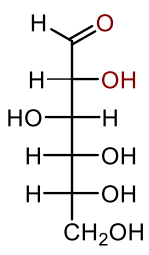

Glucose (1)

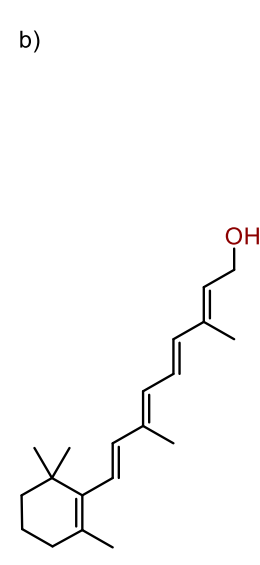

Vitamine A (3)
Fischer (1884)

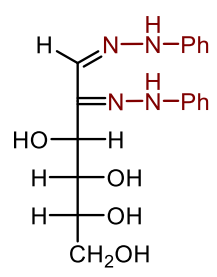

Glucosazone (2)
Scheme 1- Prominent historical examples of derivatizations which improve crystallinity

Of those derivatization techniques with historical importance ${ }^{34}$ only the nitrobenzoate derivatization remained and is still routinely used to facilitate the crystallization of difficult samples. ${ }^{35}$ Unfortunately, this auxiliary does not introduce a heavy atom or a chiral reference center which would help assigning the absolute configuration by means of X-ray crystallography.

We have identified ferrocene derivatization as a simple and efficient technique for obtaining single crystals. We have found it very useful for establishing the absolute configuration and will start by introducing the rationale behind this idea.

\section{Concept}

Facing the challenge to establish the absolute configuration of a scalemic, liquid sample we were looking for an operationally simple way to solve this problem. We sought to render oily organic substrates crystalline by covalently linking it to an organometallic compound with high melting point and good crystallinity. For this purpose ferrocene carboxylic acid seems to be the ideal candidate as it combines several attractive properties:

\section{- Highly crystalline}

- Contains a heavy atom for increased diffraction intensity 
- Intense anomalous scattering effect allowing for the determination of the absolute structure

- Chemically and thermally stable

- Characteristic orange color

- High sensitivity to electrospray mass spectrometry ${ }^{36-38}$

- Relatively cheap or easily synthesized from ferrocene $^{39}$

Based on seminal work by Shibata (vide infra), ${ }^{40-42}$ we identified ferrocene carboxylic acid as ideal auxiliary that could be easily reacted under mild conditions with liquid chiral molecules containing either an alcohol and/or amine functionality. Either one of these two functional groups is found in most natural products, APIs and in many synthetic intermediates. Therefore, we reasoned that this method should be broadly applicable.

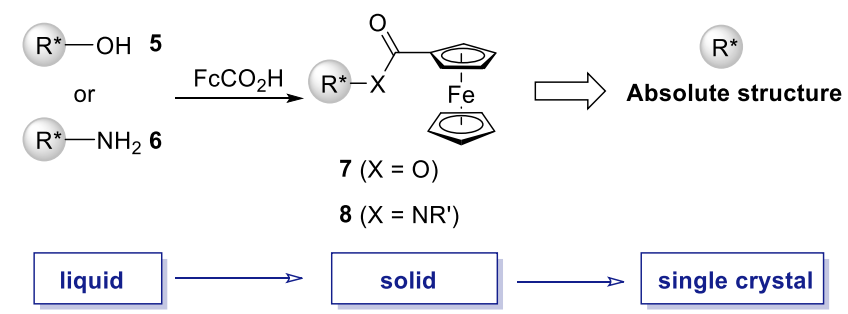

Scheme 2 - Concept of ferrocene derivatization to transfer liquid, chiral substrates into crystalline solids

Herein, we will a) analyze the synthetic scope, b) discuss the capacities of the method to increase the melting point and yield high quality crystallographic data suitable for unequivocal assignment of the absolute configuration and c) comment on its limitations.

\section{Results and Discussion}

\subsection{Synthetic part}

\subsubsection{Initial proof of concept}

With the above detailed considerations in mind, we set to test our idea for the first time on indane $\mathbf{6 a}$. The correct analysis of its precursor 9 was a center piece to our report on a catalytic asymmetric $\mathrm{C}\left(\mathrm{sp}^{3}\right)-\mathrm{H}$ activation and allowed to resolve a contradiction between a previous assignment of the absolute configuration and a DFT study. ${ }^{43}$ The liquid nitrile 9 was reduced to the liquid amine $\mathbf{6 a}$, which was finally converted into the solid ferrocenyl amide $\mathbf{8 a}$ by reacting with commercially available ferrocene carboxylic acid. The large $(0.60 \times 0.48 \times 0.34$ $\mathrm{mm})$ single crystal obtained gave excellent diffraction data and allowed to establish the $R, R$-configuration of indane 8a with high certainty (Flack $\mathrm{x}=0.006(12)$ ). Of note, the corresponding amide derived from 3-bromo benzoic acid remained a liquid and did not allow for crystallographic analysis. ${ }^{44}$

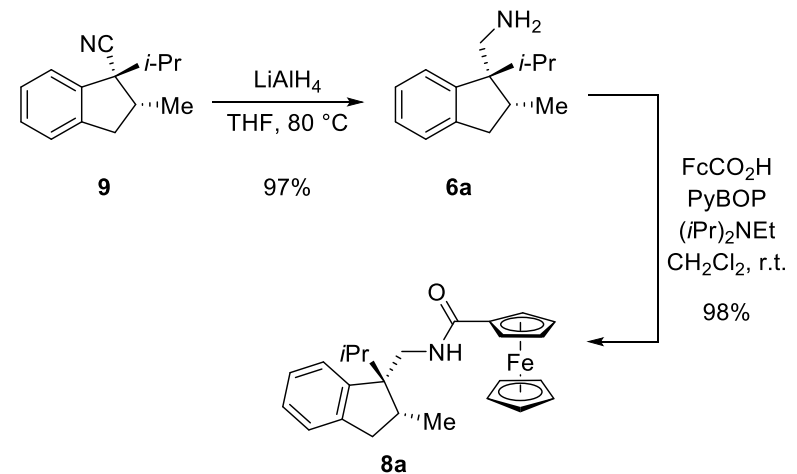

Scheme 3 - Ferrocene derivatization and crystallization of a chiral indane ${ }^{43}$

Encouraged by our first example which enabled facile crystallization and resulted in high quality X-ray diffraction data, the ferrocene derivatization was applied in the total synthesis of aeruginosins. ${ }^{45,46}$ The preparation of the octahydroindole core of these molecules involved a nucleophilic substitution step on dibromocyclohexenol $\mathbf{1 0}$ to give intermediate 13, required clarification of the stereochemical outcome. Whereas this reaction had been reported previously to proceed with high cis selectivity with sodium azide as nucleophile, ${ }^{47}$ the nucleophilic substitution followed by $\mathrm{C}\left(\mathrm{sp}^{3}\right)-\mathrm{H}$ activation led to an aeruginosin fragment of trans-configuration. To clarify the outcome of the substitution step, compound $\mathbf{1 1}$ and $\mathbf{1 2}$ were prepared. Structural elucidation by NOE NMR would have been particular challenging and so ferrocene derivatization was applied. After deprotection of the alcohol, Steglich esterification with ferrocene carboxylic acid gave $\mathbf{7 a}$ and $\mathbf{7 b}$ as orange solids. Suitable crystals for X-ray crystallography were obtained in the first recrystallization attempt. The crystal structures of $\mathbf{7 a}$ and $\mathbf{7 b}$ allowed establishing the stereodivergent behavior for the nucleophilic substitution of $\mathbf{1 0}$ with different nucleophiles.

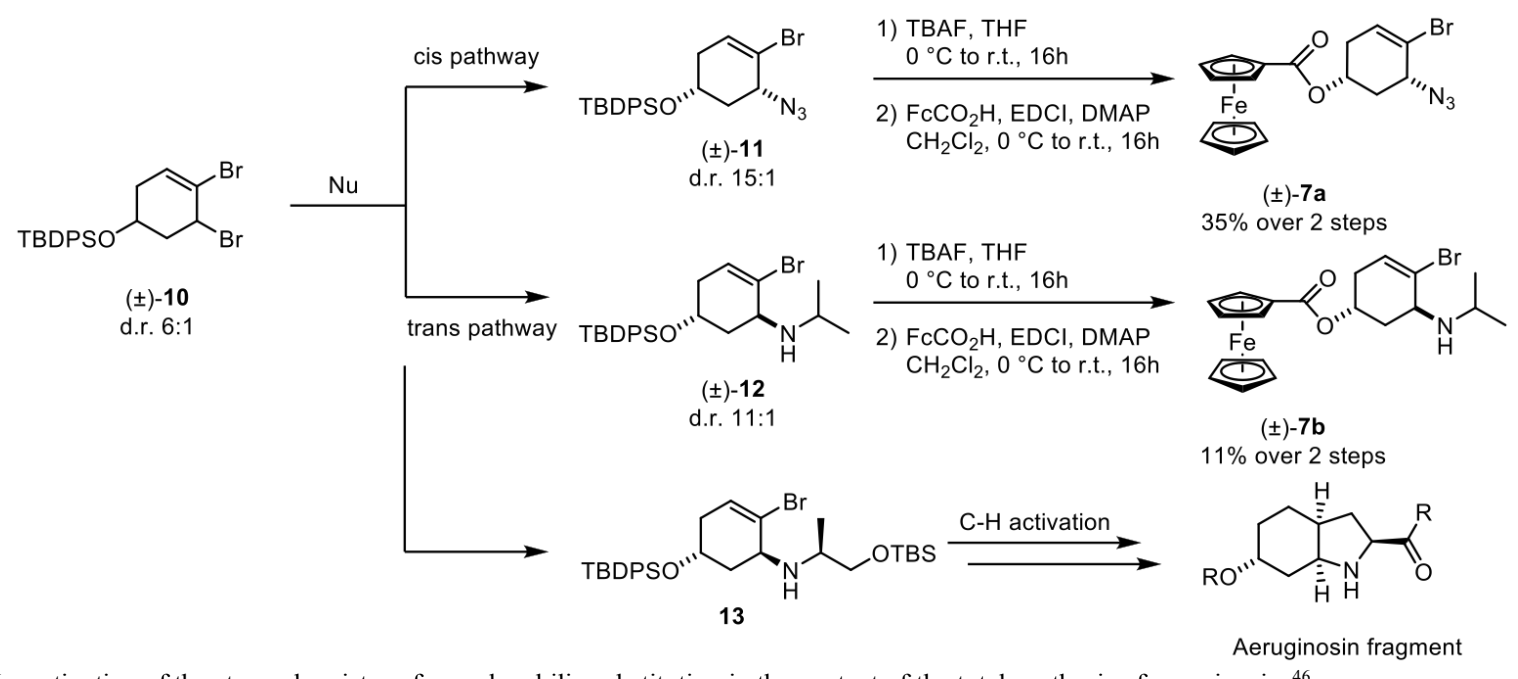

Scheme 4 -Investigation of the stereochemistry of a nucleophilic substitution in the context of the total synthesis of aeruginosins ${ }^{46}$ 

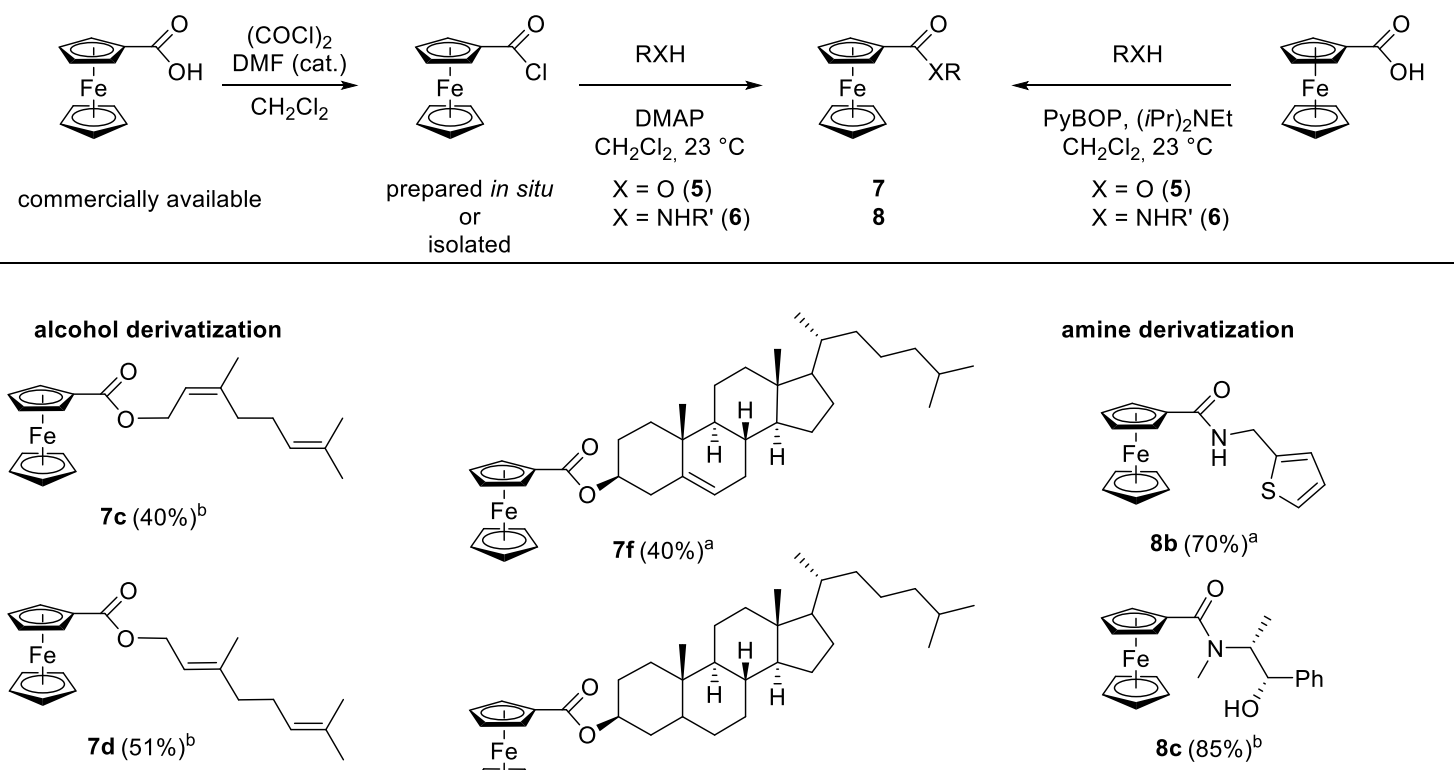

amine derivatization

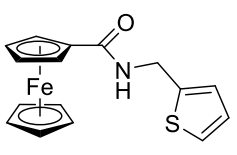

$8 \mathbf{b}(70 \%)^{a}$

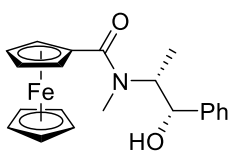

$8 \mathrm{c}(85 \%)^{\mathrm{b}}$

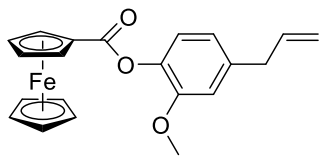

7 e $(97 \%)^{a}$

Scheme 5 - Ferrocene derivatization of representative liquid or chiral alcohol and amine substrates, reaction conditions: ${ }^{\mathrm{a}}$ method A, ${ }^{\mathrm{b}}$ method B

3.1.2. New ferrocenyl ester and amides

After the success of these two initial applications, we investigated the scope of the ferrocene derivatization by applying it to other chiral or liquid molecules, with a focus on natural products. Ferrocenyl esters and amides were prepared via ferrocenoyl chloride (method A) or using the activating agent PyBOP (method B). Both protocols were operationally simple and without any optimization the desired products were obtained in moderate to high yield. The oily monoterpene alcohols nerol 5c and geraniol 5d were converted into the corresponding ferrocene carboxylates $\mathbf{7 c}$ and $\mathbf{7 d}$. The reaction can easily be conducted at small scale $(65 \mu \mathrm{mol}$ scale for $7 \mathbf{7 d})$. The characteristic orange color is a particular advantage during chromatographic purification of small amounts because it facilitates product detection. Eugenol, a phenolic fragrance molecule found in cloves, was converted efficiently into the corresponding. ferrocene carboxylate 7e. Recovery of the natural product from ferrocene carboxylates 7 is possible. After saponification of 7e using lithium hydroxide, we isolated pure eugenol $(\mathbf{5 e})$ in $75 \%$ yield. ${ }^{48}$ The ferrocenyl esters of the secondary alcohols cholesterol ${ }^{49,50} \mathbf{5}^{49,50}$ and cholestanol $\mathbf{5 g}^{51}$ were prepared through reaction with ferrocenoyl chloride at room temperature. Esters of more hindered secondary alcohols such as testosterone $^{49}$ or menthol ${ }^{52}$ could not be obtained at room temperature. Moreover, the esterification of tertiary alcohols was unsuccesful, e.g. $(R)$-linalool $(\mathbf{5 h})$ did not react at all. In the literature, the only ferrocene carboxylate issued from a tertiary alcohol was obtained by refluxing ferrocenoyl chloride in tertbutanol. ${ }^{53}$ These results show that esterification of sterically hindered alcohols is a limitation of our current synthetic strategy. Additionally, a small number of ferrocene derivatives remained liquid.

The liquid thiophene building block $\mathbf{6} \mathbf{b}$ was converted into the amide $\mathbf{8 b}$ solid product by reacting with ferrocene carboxylic acid. As expected, the secondary amine ephedrine reacted selectively at the nitrogen atom in the presence of free hydroxyl group when using peptide coupling conditions.

The derivatization of two sterically hindered amines was described by one of us recently ${ }^{54}$ Chiral indoline carbamates $\mathbf{1 4}$, obtained from asymmetric $\mathrm{C}\left(\mathrm{sp}^{3}\right)-\mathrm{H}$ activation are liquid substances. Therefore, 14d-e were deprotected to the $\mathrm{N}-\mathrm{H}$ indolines 6d-e and converted into the corresponding ferrocene carboxamides. Whereas 8d could be prepared using classical conditions, $8 \mathbf{e}$ required the generation of the lithium amide which was then reacted with ferrocenoyl chloride.

For all above described liquid molecules we were able to obtain single crystals of high quality through ferrocene derivatization. Crystal structures obtained were of high quality and allowed to determine the absolute configuration for all chiral molecules (vide infra).

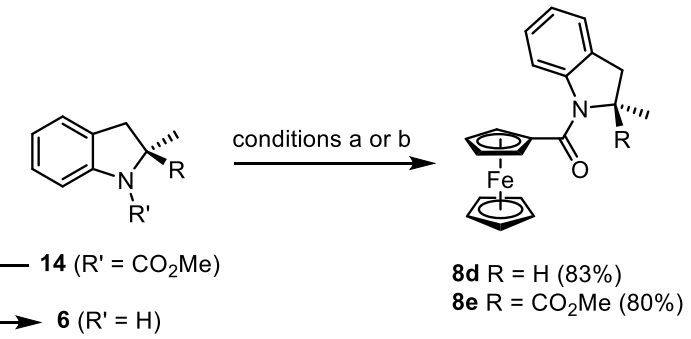

Scheme 6 - Preparation of tertiary ferrocenyl amides ${ }^{54}$ reaction conditions: a) DMAP, $i \mathrm{Pr}_{2} \mathrm{NEt}$, $\mathrm{FcCOCl}, \mathrm{CH}_{2} \mathrm{Cl}_{2}$, b) LiHMDS, THF, $-78^{\circ} \mathrm{C}$, then $\mathrm{FcCOCl}$, $-10^{\circ} \mathrm{C}$.

3.1.3. Structures published by other groups 

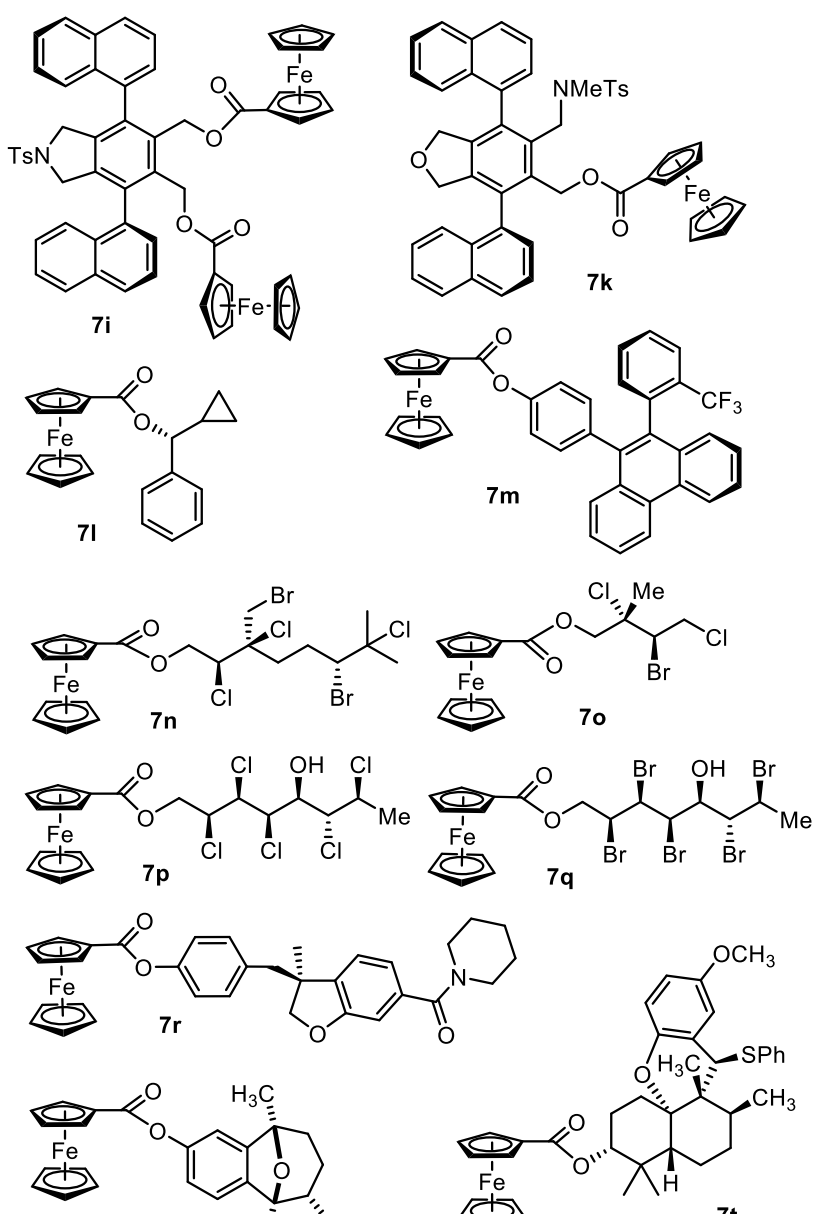

$( \pm)-7 \mathrm{~s} \quad \mathrm{H}_{3} \stackrel{\mathrm{C}}{\mathrm{C}}$ "OBoc

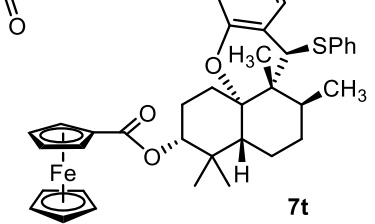

Figure 1 - Further examples of successful utilization of ferrocene derivatization for crystallization

Shibata and coworkers have used ferrocene derivatization with the purpose to obtain single crystals already in 2006. Indeed, they described the first two examples of ferrocene carboxylates which allowed X-ray analysis and the absolute structure determination of $7 \mathbf{i}-\mathbf{k} .{ }^{40}$ In the following years application to the chiral alcohols 7l-m and the determination of their absolute configuration was reported. ${ }^{41,42}$ Although some structures already contained a heavy atom, the ferrocene moiety has most likely helped in the recrystallization process. Burns and co-workers have applied the ferrocene derivatization to synthetic intermediates of the halogenated terpene (+)-halomon and found the ferrocene carboxylates "as being particularly valuable in cases where common benzoate and sulfonate derivatives fail to induce adequate crystallinity." 55 The same group also prepared the polyhalogenated structures $\mathbf{7 p - q}$ and studied their conformation in the solid state. ${ }^{56}$ In both cases the primary alcohol reacts selectively in the presence of a secondary alcohol. Brown et al. determined the absolute configuration of $7 \mathbf{r} .^{57}$ Magauer et al. determined the constitution of racemic $7 \mathbf{s}^{58}$ and the absolute structure of $\mathbf{5 t}$, an intermediate in the total synthesis of (-)cyclosmenospongine, ${ }^{59}$ via crystallization of the ferrocene carboxylate 7t. The later demonstrates that a sterically hindered neopentylic alcohol can be efficiently converted $(70 \%)$ at room temperature.
The independent application by different international research groups underlines that a powerful and operationally simple method to introduce a heavy atom containing moiety has been found.

\subsection{Physical properties}

\subsubsection{Melting point:}

As discussed before, derivatization with $p$-nitrobenzoic acid has been used for a long time to deliver solids with sharp melting points from samples of poor crystallinity. A related, measureable effect is the increase in melting point that the $p$-nitrobenzoyl derivatization can induce. As a consequence it converts certain liquid samples into solids and thus allow for crystallization. In order to critically assess the utility of the ferrocene derivatization for liquid samples, we wanted to compare the melting points of ferrocene and $p$-nitrobenzoate derivatives of the same compound. We included the herein described compounds (5c-5f, 6b-c) as well as literature known derivatives $(\mathbf{5 u}-\mathbf{z}, \mathbf{6} \mathbf{f}-\mathbf{-})^{48}$.

In general, the melting points of both derivatives are quite similar (Figure 2) and for example the essential oil extract geraniol (5d) was converted into a solid by both approaches. Only sporadically (e.g. $\mathbf{5 e}, \mathbf{5 v}$ or $\mathbf{6 c}$ ) marked differences between both derivatives can be noted. Although the comparison is of limited significance, it shows that ferrocene derivatization is as powerful as $p$-nitrobenzoyl for the conversion of liquid samples $(\mathbf{5 c}-\mathbf{e}, \mathbf{v}, \mathbf{w}, \mathbf{z}$ and $\mathbf{6 b}, \mathbf{f}-\mathbf{h}, \mathbf{k})$ into solids.

a)

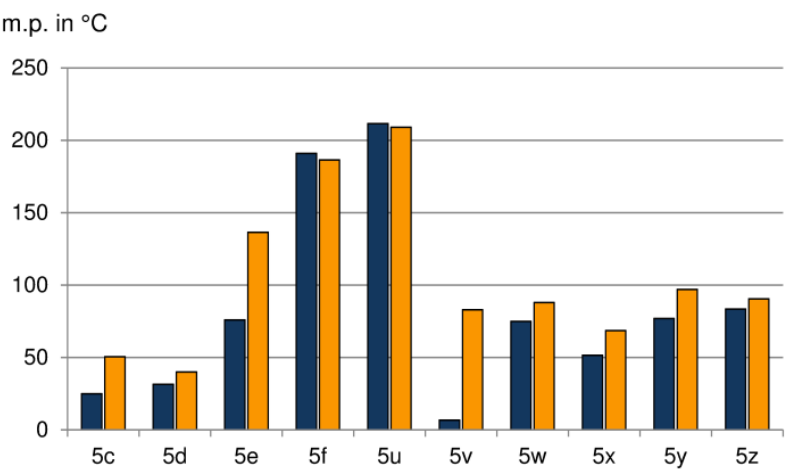

b)

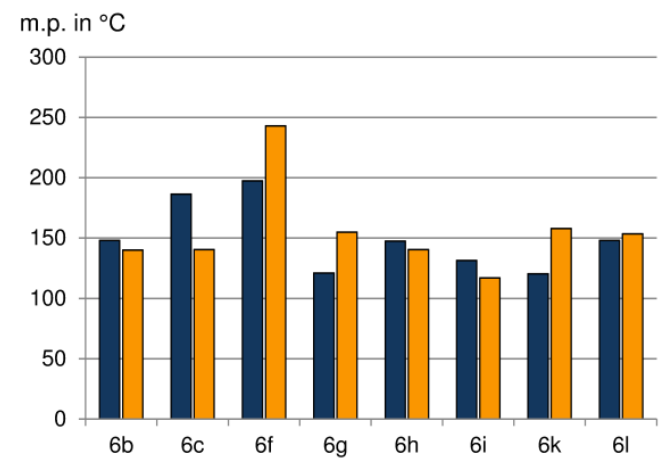

Figure 2 - Comparison of the melting points of a) ester derived from alcohols 5 and b) amides derived from amines $\mathbf{6}$ (orange: ferrocene derivatives, blue: $p$-nitrobenzoyl derivatives; average values are plotted for melting points which were reported as temperature ranges). ${ }^{48}$

\subsubsection{Crystallographic data}


Single crystals suitable for X-ray diffraction analysis of 7c, $7 \mathrm{e}-\mathrm{g}$ and $\mathbf{8 b - c}$ were obtained by recrystallization. The ability to obtain crystal structure of 7c and 7e (Figure 3) is particularly remarkable since the original compounds are oily liquids. Crystal structures of the steroid derivatives $\mathbf{7 f - g}$ and ephedrine derivative $\mathbf{8 c}$ are good examples of absolute configuration determination for compounds possessing only light atoms Recrystallization was mostly carried out by vapor diffusion (for crystal structures in Figure 3) and crystals with edge length $\geq 0.5 \mathrm{~mm}$ are not rare (table 1). In some cases the crystal obtained was too large for a modern rotating anode with focusing mirrors and had to be cut to conduct the X-ray experiment.

The crystallographic data of the above described ferrocene derivatives are listed in Table 1 . When structure factors of compounds previously reported in the literature were available, the structures were re-refined using SHELXL. ${ }^{60}$ As it was pointed out that methods of Parsons and Hooft improve the precision of the enantiopure distinguishing parameter in a similar way, ${ }^{61}$ we calculate it using Parsons quotients here. Most crystal structures have excellent $R_{1}$ values ( $\geq 0.05$ ) with exception of $7 \mathbf{m}$ (Table 1 ).

Figure 3-Crystal structures of $\mathbf{7 c}, \mathbf{7 e}, \mathbf{7 f}, \mathbf{7 g}, \mathbf{8 b}, \mathbf{8 c}$ (Ortep representation with thermal ellipsoids at $50 \%$ probability)

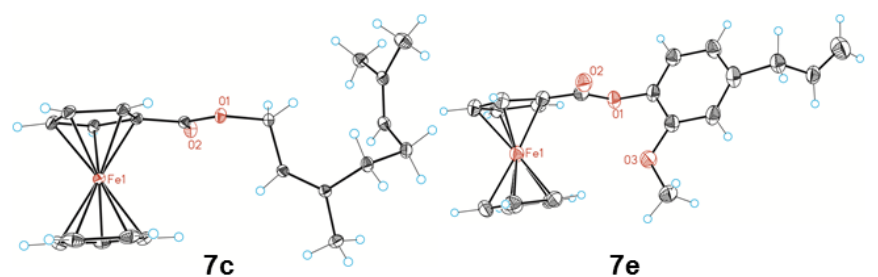

$7 c$

$7 e$
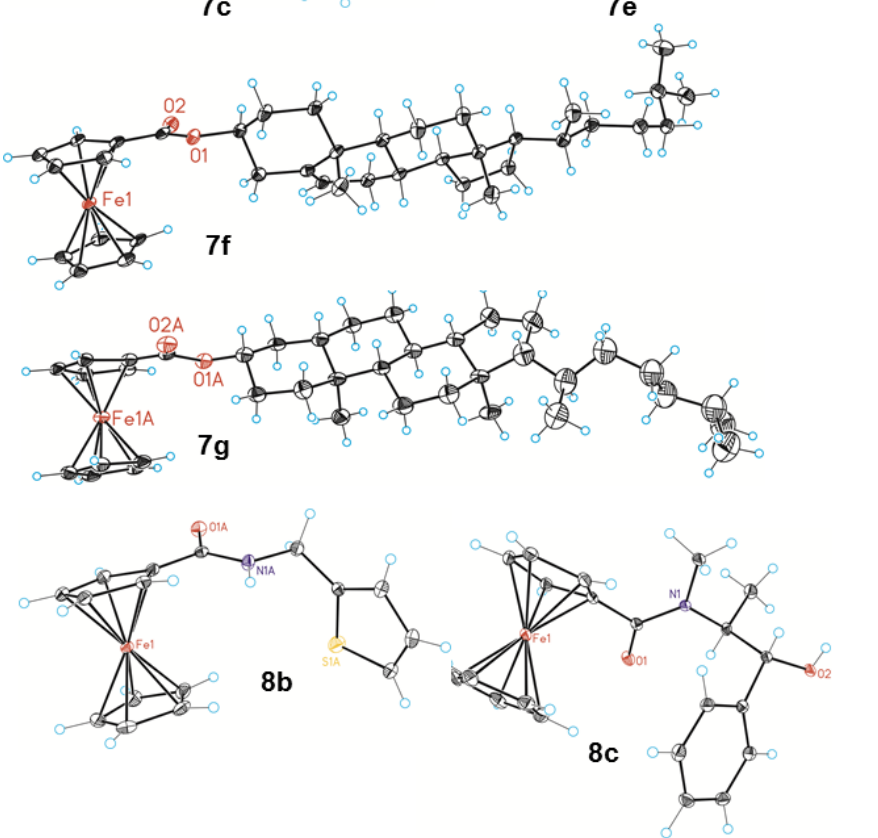

Table 1 - crystal data obtained from new or previously reported ferrocene derivatives

\begin{tabular}{|c|c|c|c|c|c|c|c|}
\hline No. & R1 & wR2 & GooF & Radiation type & $\begin{array}{c}\text { Crystal system, } \\
\text { space group }\end{array}$ & Crystal size in $\mathbf{m m}$ & Flack $x^{a}$ \\
\hline$( \pm)-7 \mathbf{a}^{46}$ & 0.0499 & 0.0471 & 1.0423 & $\operatorname{MoK} \alpha$ & Triclinic, $P \overline{1}$ & $0.47 \times 0.38 \times 0.12$ & - \\
\hline$( \pm)-7 b^{46}$ & 0.0468 & 0.1038 & 1.005 & $\operatorname{MoK} \alpha$ & Monoclinic, $P 2_{1}$ & $0.55 \times 0.27 \times 0.20$ & $0.017(16)^{\mathrm{a}}$ \\
\hline $7 \mathrm{c}$ & 0.0323 & 0.0799 & 1.080 & $\operatorname{MoK} \alpha$ & Monoclinic, $P 2_{1} / \mathrm{n}$ & $0.40 \times 0.04 \times 0.02$ & - \\
\hline $7 e$ & 0.0532 & 0.1358 & 1.088 & $\operatorname{MoK} \alpha$ & Triclinic, $P \overline{1}$ & $0.35 \times 0.25 \times 0.15$ & - \\
\hline $7 f$ & 0.0478 & 0.1283 & 1.059 & $\mathrm{MoK} \alpha$ & Monoclinic, $C 2$ & $0.10 \times 0.05 \times 0.03$ & $0.026(16)$ \\
\hline $7 \mathrm{~g}$ & 0.0761 & 0.1870 & 1.014 & $\operatorname{MoK} \alpha$ & Triclinic, $P 1$ & $0.10 \times 0.05 \times 0.05$ & $-0.001(14)$ \\
\hline $7 i^{40}$ & 0.0435 & 0.1136 & 0.986 & $\operatorname{MoK} \alpha$ & Monoclinic, $P 2_{1}$ & $0.60 \times 0.20 \times 0.20$ & $0.000(12)^{\mathrm{c}}$ \\
\hline $7 \mathbf{k}^{40}$ & 0.0856 & 0.2138 & 0.914 & $\operatorname{MoK} \alpha$ & Orthorhombic, $P 2{ }_{1} 2_{1} 2_{1}$ & $0.40 \times 0.40 \times 0.10$ & $0.06(4)^{\mathrm{c}}$ \\
\hline $71^{41}$ & 0.0317 & 0.0745 & 1.019 & $\operatorname{MoK} \alpha$ & Monoclinic, $P 2_{1}$ & $0.80 \times 0.50 \times 0.40$ & $0.011(13)^{\mathrm{c}}$ \\
\hline $7 m^{42}$ & 0.1672 & 0.3666 & 1.001 & $\operatorname{MoK} \alpha$ & Monoclinic, $P 2_{1}$ & $0.75 \times 0.29 \times 0.18$ & $-0.01(4)^{\mathrm{c}}$ \\
\hline $7 n^{55}$ & 0.0533 & 0.1103 & 1.051 & $\operatorname{MoK} \alpha$ & Monoclinic, $P 2_{1}$ & $0.16 \times 0.15 \times 0.06$ & $0.053(5)$ \\
\hline $70^{55}$ & 0.0187 & 0.0478 & 1.032 & $\operatorname{MoK} \alpha$ & Monoclinic, $P 2_{1}$ & $0.27 \times 0.18 \times 0.08$ & $0.025(3)$ \\
\hline $7 p^{56}$ & 0.0228 & 0.0481 & 0.994 & $\operatorname{MoK} \alpha$ & Triclinic, $P 1$ & $0.29 \times 0.09 \times 0.04$ & $0.006(5)$ \\
\hline $7 \mathbf{q}^{56}$ & 0.0301 & 0.0671 & 1.111 & $\operatorname{MoK} \alpha$ & Monoclinic, $P 2_{1} / \mathrm{n}$ & $0.08 \times 0.07 \times 0.04$ & $-{ }^{d}$ \\
\hline$( \pm)-7 \mathbf{s}^{58}$ & 0.0412 & 0.0892 & 1.070 & $\operatorname{MoK} \alpha$ & Triclinic, $P \overline{1}$ & $0.10 \times 0.06 \times 0.02$ & - \\
\hline $7 t^{59}$ & 0.0447 & 0.0792 & 1.039 & $\operatorname{MoK} \alpha$ & Monoclinic, $P 2_{1}$ & $0.10 \times 0.03 \times 0.01$ & $0.008(10)$ \\
\hline $8 \mathbf{a}^{43}$ & 0.0327 & 0.0818 & 1.109 & $\operatorname{MoK} \alpha$ & Orthorhombic, $P 2{ }_{1} 2_{1} 2_{1}$ & $0.60 \times 0.48 \times 0.34$ & $0.006(12)^{\mathrm{c}}$ \\
\hline $8 \mathbf{b}$ & 0.0309 & 0.0809 & 1.039 & $\operatorname{MoK} \alpha$ & Monoclinic, $P 2_{1} / \mathrm{c}$ & $0.20 \times 0.15 \times 0.10$ & - \\
\hline $8 c$ & 0.0225 & 0.0632 & 1.062 & $\mathrm{MoK} \alpha$ & Monoclinic, $P 2_{1}$ & $0.20 \times 0.15 \times 0.10$ & $0.007(7)$ \\
\hline $\mathbf{8 d}^{54}$ & 0.0450 & 0.1192 & 1.096 & $\mathrm{GaK} \alpha$ & Orthorhombic, $P 2{ }_{1} 2_{1} 2_{1}$ & $0.70 \times 0.30 \times 0.20$ & $0.000(12)$ \\
\hline $8 \mathrm{e}^{54}$ & 0.0380 & 0.1098 & 1.040 & $\mathrm{GaK} \alpha$ & Trigonal, $P 3_{2}$ & $0.11 \times 0.07 \times 0.03$ & $0.026(9)$ \\
\hline
\end{tabular}

${ }^{\text {a }}$ Recalculated Flack parameter using the quotient method according to Parsons

${ }^{\mathrm{b}}$ The racemic compound crystalized as conglomerate yielding an enantiopure crystal.

${ }^{\mathrm{c}}$ Originally published Flack parameter, see reference in column 1.

${ }^{\mathrm{d}}$ The compound with an optical purity of $80 \% e e^{56}$ crystalized as racemate. 


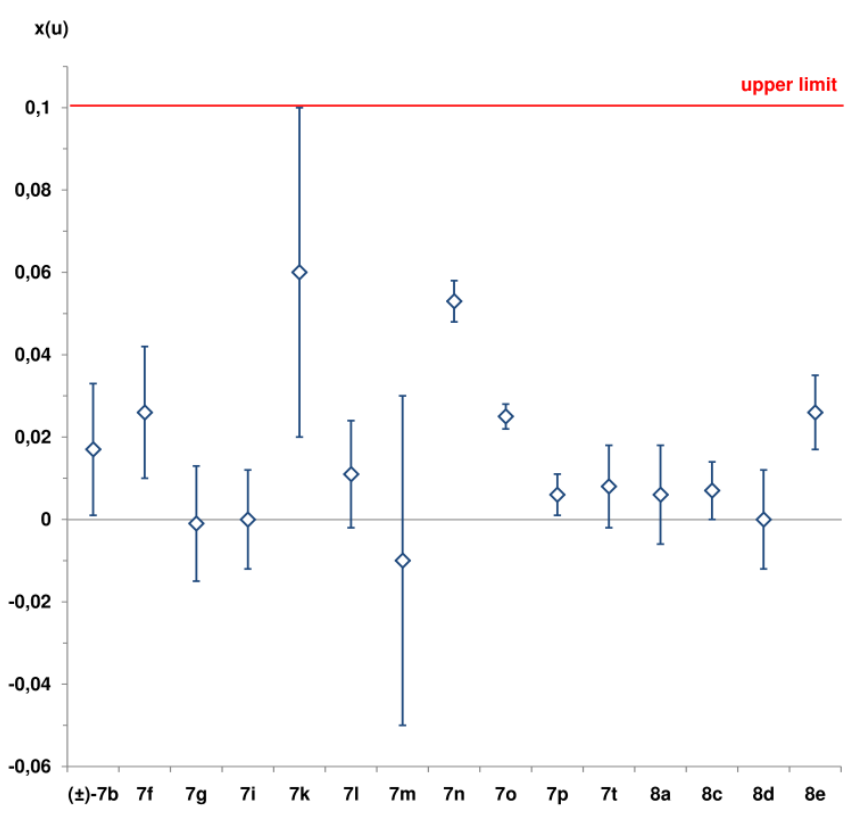

Figure 4 -Flack parameter using quotient method according to Parsons with $1 \sigma$ uncertainty

All crystal structures in table 1 were measured on either MoK $\alpha$ or GaK $\alpha$ radiation. All crystal structures are characterized of excellent absolute structure parameters (Figure 4). The limit for enantiopure compounds defined by Flack of $\mathrm{x}(\mathrm{u}) \leq 0.1(1)$ was easily met and in most cases the parameter and its standard deviation were significantly smaller than $x \geq 0.10(4)$ defined by Flack. ${ }^{13}$ In summary, the ferrocene derivatization of a variety of liquid chiral molecules allowed obtaining single crystals suitable for X-ray crystallography which enabled us and others to unambiguously assign their absolute configuration.

\section{Conclusion}

We have outlined the concept of derivatizing small molecules with ferrocene carboxylic acid in order to obtain suitable crystals for X-ray diffraction analysis. Seven new crystal structures of ferrocenyl ester and amides containing natural products and synthetic building blocks are reported. Together with previous applications in total syntheses and asymmetric catalysis these examples underline that the derivatization of small molecules with ferrocene carboxylic acid is an operationally simple method to obtain crystals of good quality. The strength of the technique lies in the ability to convert liquid samples into solids and to introduce a heavy atom for absolute structure determination. The crystallographic data sets obtained are of high quality and all absolute structures were unambiguously determined using MoK $\alpha$ or $\mathrm{GaK} \alpha$ radiation.

The method has been successful applied in 23 cases, but we also experienced some limitations, as derivatizing tertiary alcohols did not succeed in our hands. That said, the method was found to be superior to other derivatizations in some examples. It is based on a simple manipulation, standard equipment and a commercial reagent which makes it easily accessible for synthetic chemists. Further application in total synthesis and asymmetric synthesis are expected in the future.

\section{Experimental}

\subsection{General}

Ferrocene carboxylic acid (CAS: 1271-42-7) was purchased from Sigma Aldrich. Ferrocenoyl chloride ${ }^{62}$ was prepared following standard protocol using oxalyl chloride in dichloromethane with a catalytic amount of DMF and stored in the glovebox. Alternatively, Ferrocenoyl chloride can be purchased from Sigma Aldrich (CAS: 1293-79-4). The reactions were carried out under argon atmosphere in solvents dried by passing through an activated alumina column on a PureSolv TM solvent purification system (Innovative Technologies, Inc., MA). Purifications were carried out on a CombiFlash ${ }^{\circledR} \mathrm{Rf}^{+}$apparatus. Organic solutions were concentrated under reduced pressure on a Büchi rotary evaporator. NMR spectra were recorded at $23{ }^{\circ} \mathrm{C}$ on a Bruker Avance 400 Ultrashield and Bruker Avance 500 Ultrashield apparatus. Mass spectra were recorded on a Waters LCT Premier Spectrometer. Melting points were determined using a Büchi melting point apparatus. Crystal structure determination for compounds $\mathbf{7 f}, \mathbf{7 g}, \mathbf{7 e}, \mathbf{8 b}$ and $\mathbf{8 c}$ was carried out using a Rigaku diffractometer equipped with a Pilatus $200 \mathrm{~K}$ area detector, a Rigaku MicroMax-007HF microfocus rotating anode with $\mathrm{MoK}_{\alpha}$ radiation, Confocal Max Flux optics and an Oxford Cryosystems low temperature device Cryostream 700 plus $\left(T=-173^{\circ} \mathrm{C}\right)$. Crystal structure determination for compound 7c were carried out using a Apex DUO diffractometer equipped with a Kappa 4-axis goniometer, an APEX II 4K CCD area detector, a Microfocus Source E025 IuS using $\mathrm{MoK}_{\alpha}$ radiation, Quazar MX multilayer Optics as monochromator and an Oxford Cryosystems low temperature device Cryostream 700 plus $(T=-$ $\left.173{ }^{\circ} \mathrm{C}\right)$. Crystal structures can be obtained free of charge from the Cambridge Crystallographic Data Centre under the deposit numbers.

\subsection{Neryl ferrocene carboxylate $7 c$}

To a suspension of ferrocenecarboxylic acid (82 mg, 0.357 mmol, 1.1 equiv), nerol (50 mg, $0.324 \mathrm{mmol}, 1.0$ equiv), DMAP (7.9 mg, $0.065 \mathrm{mmol}, 0.2$ equiv) and DIPEA $(0.113 \mathrm{~mL}, 0.648$ mmol, 2.0 equiv) in DCM $(2 \mathrm{~mL})$ was added PyBOP $(186 \mathrm{mg}$, $0.357 \mathrm{mmol}, 1.1$ equiv). The reactions mixture turns into an orange solution and was stirred at r.t. for $16 \mathrm{~h}$. The reaction mixture was quenched with brine, diluted with EtOAc and the phases were separated. The aq. layer was extracted with EtOAc twice and the combined org. extracts were concentrated under reduced pressure. The crude product was purified by flash chromatography (12 $\mathrm{g} \mathrm{SiO}_{2}$, gradient: $0 \%$ to $3 \%$ EtOAc in CyHex) affording $47 \mathrm{mg}(0.128 \mathrm{mmol}, 40 \%)$ of an orange oil which can be crystalized. Single crystals were obtained by vapor diffusion using $\mathrm{Et}_{2} \mathrm{O}$ (solvent) and ethanol (anti-solvent).

${ }^{1} \mathrm{H}$ NMR $\left(500 \mathrm{MHz}, \mathrm{CDCl}_{3}\right) \delta 5.49-5.43(\mathrm{~m}, 1 \mathrm{H}), 5.17-$ $5.12(\mathrm{~m}, 1 \mathrm{H}), 4.82-4.79(\mathrm{~m}, 2 \mathrm{H}), 4.71(\mathrm{dd}, \mathrm{J}=7.2,0.8 \mathrm{~Hz}, 2 \mathrm{H})$, $4.39-4.35(\mathrm{~m}, 2 \mathrm{H}), 4.19(\mathrm{~s}, 5 \mathrm{H}), 2.23-2.17(\mathrm{~m}, 2 \mathrm{H}), 2.16-$ $2.10(\mathrm{~m}, 2 \mathrm{H}), 1.79(\mathrm{~d}, \mathrm{~J}=1.2 \mathrm{~Hz}, 3 \mathrm{H}), 1.70(\mathrm{~d}, \mathrm{~J}=0.9 \mathrm{~Hz}, 3 \mathrm{H})$, $1.63(\mathrm{~s}, 3 \mathrm{H}) ;{ }^{13} \mathrm{C}$ NMR $\left(126 \mathrm{MHz}, \mathrm{CDCl}_{3}\right) \delta 171.6,142.3,132.2$, 123.7, 119.8, 71.5, 71.2 (2C), 70.2 (2C), 69.7 (5C), 60.8, 32.3, 26.8, 25.7, 23.6, 17.7; M.p.: 50-51 ${ }^{\circ} \mathrm{C}$; HRMS-ESI: calculated for $\mathrm{C}_{21} \mathrm{H}_{26} \mathrm{FeNaO}_{2}[\mathrm{M}+\mathrm{Na}]^{+}$: 389.1175; found: 389.1170 .

\subsection{Geranyl ferrocene carboxylate $7 d$}

To a suspension of ferrocenecarboxylic acid (16 mg, 0.071 mmol, 1.1 equiv), geraniol (10 $\mathrm{mg}, 0.065 \mathrm{mmol}, 1.0$ equiv), DMAP (1 mg, 0.008 mmol, 0.1 equiv) and $\mathrm{Et}_{3} \mathrm{~N}(0.018 \mathrm{~mL}$, 0.130 mmol, 2.0 equiv) in DCM (1 mL) was added PyBOP (37 $\mathrm{mg}, 0.071 \mathrm{mmol}, 1.1$ equiv). The reactions mixture turns into an orange solution and was stirred at r.t. for $16 \mathrm{~h}$. The reaction mixture was quenched with brine, diluted with EtOAc and the phases were separated. The aq. layer was extracted with EtOAc twice and the combined org. extracts were concentrated under reduced pressure. The crude product was purified by flash chromatography (12 $\mathrm{g} \mathrm{SiO}_{2}$, gradient: $0 \%$ to $4 \%$ EtOAc in CyHex) affording $12 \mathrm{mg}(0.033 \mathrm{mmol}, 51 \%)$ of an orange oil which solidifies upon standing. 
${ }^{1} \mathrm{H}$ NMR $\left(400 \mathrm{MHz}, \mathrm{CDCl}_{3}\right) \delta 5.48(\mathrm{~m}, 1 \mathrm{H}), 5.16-5.10(\mathrm{~m}$, $1 \mathrm{H}), 4.83(\mathrm{t}, \mathrm{J}=1.9 \mathrm{~Hz}, 2 \mathrm{H}), 4.76(\mathrm{~d}, \mathrm{~J}=7.0 \mathrm{~Hz}, 2 \mathrm{H}), 4.40(\mathrm{t}, \mathrm{J}=$ $1.9 \mathrm{~Hz}, 2 \mathrm{H}), 4.22(\mathrm{~s}, 5 \mathrm{H}), 2.21-2.06(\mathrm{~m}, 4 \mathrm{H}), 1.81(\mathrm{~s}, 3 \mathrm{H}), 1.71$ $(\mathrm{d}, \mathrm{J}=0.7 \mathrm{~Hz}, 3 \mathrm{H}), 1.63(\mathrm{~s}, 3 \mathrm{H}) ;{ }^{13} \mathrm{C} \mathrm{NMR}\left(126 \mathrm{MHz}, \mathrm{CDCl}_{3}\right) \delta$ $171.7,142.0,131.8,123.8,118.9,71.4,71.2(2 \mathrm{C}), 70.2(2 \mathrm{C})$, 69.7 (5C), 61.1, 39.6, 26.3, 25.7, 17.7, 16.6; M.p.: 39-41 ${ }^{\circ} \mathrm{C}$; HRMS-ESI: calculated for $\mathrm{C}_{21} \mathrm{H}_{26} \mathrm{FeNaO}_{2}[\mathrm{M}+\mathrm{Na}]^{+}$: 389.1175; found: 389.1171 .

\subsection{Eugenyl ferrocene carboxylate $7 e$}

To a suspension of ferrocenecarboxylic acid (57.4 mg, 0.250 mmol, 1.4 equiv) in DCM $(1 \mathrm{~mL})$ were added oxalyl chloride $(0.021 \mathrm{~mL}, 0.245 \mathrm{mmol}, 1.3$ equiv) and three drops of dry DMF at $0{ }^{\circ} \mathrm{C}$. After the gas evolution ceased and the reaction mixture turned into a clear solution, it was stirred for $0.5 \mathrm{~h}$ at r.t. Then, a solution of eugenol (30 mg, $0.183 \mathrm{mmol}, 1.0$ equiv) and DMAP (61 mg, $0.499 \mathrm{mmol}, 2.7$ equiv) in DCM (1 mL) was added and the reaction mixture was stirred for $16 \mathrm{~h}$ at r.t. The reaction mixture was quenched by adding a small amount of silica gel and concentrating to dryness. The crude product was purified by flash chromatography (12 $\mathrm{g} \mathrm{SiO}_{2}$, gradient: $0 \%$ to $10 \%$ EtOAc in CyHex) affording $67 \mathrm{mg}(0.178 \mathrm{mmol}, 97 \%)$ of an orange solid. Single crystals were obtained by vapor diffusion using $\mathrm{CH}_{2} \mathrm{Cl}_{2}$ (solvent) and pentane (anti-solvent).

${ }^{1} \mathrm{H}$ NMR (400 MHz, $\left.\mathrm{CDCl}_{3}\right) \delta 7.03(\mathrm{~d}, \mathrm{~J}=8.0 \mathrm{~Hz}, 1 \mathrm{H}), 6.89-$ $6.80(\mathrm{~m}, 2 \mathrm{H}), 6.02(\mathrm{ddt}, \mathrm{J}=16.8,10.1,6.7 \mathrm{~Hz}, 1 \mathrm{H}), 5.19-5.10$ $(\mathrm{m}, 2 \mathrm{H}), 5.01-4.97(\mathrm{~m}, 2 \mathrm{H}), 4.53-4.48(\mathrm{~m}, 2 \mathrm{H}), 4.37(\mathrm{~s}, 5 \mathrm{H})$, $3.90(\mathrm{~s}, 3 \mathrm{H}), 3.43(\mathrm{~d}, \mathrm{~J}=6.7 \mathrm{~Hz}, 2 \mathrm{H}) ;{ }^{13} \mathrm{C}$ NMR $(101 \mathrm{MHz}$, $\left.\mathrm{CDCl}_{3}\right) \delta 169.9,151.4,138.9,138.1,137.3,123.1,120.9,116.2$, 112.9, 71.8 (2C), 70.8 (2C), 70.3, 70.2 (5C), 55.8, 40.2; M.p.: 136-137 ${ }^{\circ} \mathrm{C}$; HRMS-ESI: calculated for $\mathrm{C}_{21} \mathrm{H}_{20} \mathrm{FeNaO}_{3}[\mathrm{M}+\mathrm{Na}]^{+}$: 399.0654; found: 399.0652 .

\subsection{Recovery of Eugenol $5 d$ by saponification of $7 d$}

Eugenyl ferrocene carboxylate $(25 \mathrm{mg}, 0.066 \mathrm{mmol}, 1.0$ equiv) was added to test tube, dissolved in $\mathrm{THF} / \mathrm{MeOH}(0.7 \mathrm{~mL}$, ratio $3: 1$ ) and cooled to $0{ }^{\circ} \mathrm{C}$. At that temperature, an aqueous solution of lithium hydroxide $(\mathrm{c}=1 \mathrm{M}, 0.4 \mathrm{~mL}, 0.396 \mathrm{mmol}, 6.0$ equiv) was added. The reaction mixture was allowed to warm up and stirred for $16 \mathrm{~h}$ at r.t. $600 \mathrm{mg}$ silica were added and all volatiles were evaporated. The solid was loaded directly onto a column and purification by flash chromatography (12 g SiO2, 5\% to $10 \%$ EtOAc in CyHex) gave $8.2 \mathrm{mg}(0.050 \mathrm{mmol}, 75 \%)$ of a pale yellow oil. Spectral data are were in agreement with the ones previously reported. ${ }^{63}$

${ }^{1} \mathrm{H}$ NMR $\left(500 \mathrm{MHz}, \mathrm{CDCl}_{3}\right) \delta=6.88-6.81(\mathrm{~m}, 1 \mathrm{H}), 6.72-$ $6.64(\mathrm{~m}, 2 \mathrm{H}), 5.95(\mathrm{ddt}, \mathrm{J}=16.8,10.0,6.7 \mathrm{~Hz}, 1 \mathrm{H}), 5.47(\mathrm{~s}, 1 \mathrm{H})$, $5.12-5.01(\mathrm{~m}, 2 \mathrm{H}), 3.87(\mathrm{~s}, 3 \mathrm{H}), 3.32(\mathrm{dt}, \mathrm{J}=6.6,1.2 \mathrm{~Hz}, 2 \mathrm{H})$.

\subsection{Cholesteryl ferrocene carboxylate $7 f^{49,50}$}

Cholesterol (60.1 mg, $0.155 \mathrm{mmol}, 1.0$ equiv) and DMAP ( $22.0 \mathrm{mg}, 0.180 \mathrm{mmol}, 1.2$ equiv) were weight in a small vial and a solution of ferrocenoyl chloride $(56.0 \mathrm{mg}, 0.225 \mathrm{mmol}, 1.5$ equiv) in $2 \mathrm{~mL}$ DCM was added dropwise and resulted in a deep red solution which was stirred at r.t. for $16 \mathrm{~h}$. The reaction mixture was quenched by adding a small amount of silica gel and all volatiles were evaporated under reduced pressure. The crude product was purified by flash chromatography $\left(12 \mathrm{~g} \mathrm{SiO}_{2}\right.$, gradient: $0 \%$ to $10 \%$ EtOAc in CyHex, flushing with $50 \%$ EtOAc in CyHex to recovered unreacted cholesterol) affording $36.5 \mathrm{mg}$ $(0.061 \mathrm{mmol}, 40 \%)$ of an orange solid. $26.5 \mathrm{mg}(0.069 \mathrm{mmol}$, $44 \%$ ) of unreacted cholesterol were recovered. Single crystals were obtained by vapor diffusion using acetone (solvent) and pentane (anti-solvent).
${ }^{1} \mathrm{H}$ NMR $\left(500 \mathrm{MHz}, \mathrm{CDCl}_{3}\right) \delta 5.42(\mathrm{~d}, \mathrm{~J}=3.7 \mathrm{~Hz}, 1 \mathrm{H}), 4.83$ $-4.79(\mathrm{~m}, 2 \mathrm{H}), 4.79-4.73(\mathrm{~m}, 1 \mathrm{H}), 4.39-4.35(\mathrm{~m}, 2 \mathrm{H}), 4.20(\mathrm{~s}$, $5 \mathrm{H}), 2.42(\mathrm{~m}, 2 \mathrm{H}), 2.01(\mathrm{~m}, 5 \mathrm{H}), 1.75-1.64(\mathrm{~m}, 1 \mathrm{H}), 1.52(\mathrm{~m}$, $6 \mathrm{H}), 1.41-0.96(\mathrm{~m}, 14 \mathrm{H}), 1.08(\mathrm{~s}, 3 \mathrm{H}), 0.93(\mathrm{~d}, \mathrm{~J}=6.5 \mathrm{~Hz}, 3 \mathrm{H})$, $0.88(\mathrm{~d}, \mathrm{~J}=2.3 \mathrm{~Hz}, 3 \mathrm{H}), 0.86(\mathrm{~d}, \mathrm{~J}=2.2 \mathrm{~Hz}, 3 \mathrm{H}), 0.69(\mathrm{~s}, 3 \mathrm{H})$; ${ }^{13} \mathrm{C}$ NMR $\left(126 \mathrm{MHz}, \mathrm{CDCl}_{3}\right) \delta 171.2,139.9,122.8,73.7,71.9$, 71.3 (2C), 70.3 (2C), 69.9 (5C), 56.9, 56.3, 50.2, 42.5, 39.9, 39.7, $38.6,37.2,36.8,36.3,36.0,32.1,32.1,28.4,28.3,28.2,24.5$, $24.0,23.0,22.7,21.2,19.6,18.9,12.0$; M.p.: 186-187 ${ }^{\circ} \mathrm{C}$; HRMS-ESI: calculated for $\mathrm{C}_{38} \mathrm{H}_{54} \mathrm{FeNaO}_{2}[\mathrm{M}+\mathrm{Na}]^{+}$: 621.3366; found: $621.3367 ; \mathrm{a}_{\mathrm{D}}{ }^{26}=+4.7\left(c 0.5, \mathrm{CHCl}_{3}\right)$.

\subsection{Cholestanyl ferrocene carboxylate $7 g^{51}$}

To a suspension of ferrocenecarboxylic acid (29.8 mg, 0.130 mmol, 2.0 equiv) in DCM $(1 \mathrm{~mL})$ were added oxalyl chloride $(0.011 \mathrm{~mL}, 0.130 \mathrm{mmol}, 2.0$ equiv) and two drops of dry DMF at $0{ }^{\circ} \mathrm{C}$. After the gas evolution ceased and the reaction mixture turned into a clear solution, it was stirred for $0.5 \mathrm{~h}$ at r.t. Then, a solution of cholestanol $(25.2 \mathrm{mg}, 0.065 \mathrm{mmol}, 1.0$ equiv) and DMAP (39.6 mg, $0.650 \mathrm{mmol}, 5.0$ equiv) in DCM (1 mL) was added and the reaction mixture was stirred for $16 \mathrm{~h}$ at r.t. The reaction mixture was quenched by adding a small amount of silica gel and all volatiles were evaporated under reduced pressure. The crude product was purified by flash chromatography (40 $\mathrm{g} \mathrm{SiO}_{2}$, gradient: $0 \%$ to $10 \% \mathrm{Et}_{2} \mathrm{O}$ in Pentane) affording $32 \mathrm{mg}$ ( $0.178 \mathrm{mmol}, 80 \%)$ of an orange solid. Single crystals were obtained by slow evaporation of a solution of $\mathrm{CH}_{2} \mathrm{Cl}_{2}$ and Ethanol.

${ }^{1} \mathrm{H}$ NMR $\left(500 \mathrm{MHz}, \mathrm{CDCl}_{3}\right) 4.86(\mathrm{tt}, \mathrm{J}=11.2,4.9 \mathrm{~Hz}, 1 \mathrm{H})$, $4.81-4.77(\mathrm{~m}, 2 \mathrm{H}), 4.38-4.34(\mathrm{~m}, 2 \mathrm{H}), 4.19(\mathrm{~s}, 5 \mathrm{H}), 2.01-$ $1.94(\mathrm{~m}, 1 \mathrm{H}), 1.94-1.87(\mathrm{~m}, 1 \mathrm{H}), 1.87-1.74(\mathrm{~m}, 2 \mathrm{H}), 1.72-$ $1.42(\mathrm{~m}, 7 \mathrm{H}), 1.41-1.19(\mathrm{~m}, 10 \mathrm{H}), 1.17-0.96(\mathrm{~m}, 9 \mathrm{H}), 0.91(\mathrm{~d}$, $\mathrm{J}=6.8 \mathrm{~Hz}, 3 \mathrm{H}), 0.89-0.87(\mathrm{~m}, 6 \mathrm{H}), 0.86(\mathrm{~d}, \mathrm{~J}=2.3 \mathrm{~Hz}, 3 \mathrm{H})$, $0.66(\mathrm{~s}, 3 \mathrm{H}), 0.71-0.65(\mathrm{~m}, 1 \mathrm{H}) ;{ }^{13} \mathrm{C}$ NMR $\left(126 \mathrm{MHz}, \mathrm{CDCl}_{3}\right) \delta$ 171.3, 73.4, 72.1, 71.2 (2C), 70.3, 70.2, 69.9 (5C), 56.6, 56.4, $54.4,44.9,42.8,40.2,39.7,37.0,36.3,36.0,35.7,35.7,34.5$, $32.2,28.9,28.4,28.2,28.0,24.4,24.0,23.0,22.7,21.4,18.8$, 12.5, 12.2; M.p.: 191-192 ${ }^{\circ} \mathrm{C}$; HRMS-ESI: calculated for $\mathrm{C}_{38} \mathrm{H}_{56} \mathrm{FeNaO}_{2}[\mathrm{M}+\mathrm{Na}]^{+}$: 623.3523; found: $623.3531 ;[\mathrm{a}]_{\mathrm{D}}{ }^{26}=$ $+22.0\left(c 0.5, \mathrm{CHCl}_{3}\right)$.

\section{8. $\mathrm{N}$-(thiophen-2-ylmethyl)ferrocenyl amide $8 b$}

To a suspension of ferrocenecarboxylic acid (73 mg, 0.319 mmol, 1.1 equiv) in DCM ( $1 \mathrm{~mL})$ were added oxalyl chloride $(0.027 \mathrm{~mL}, 0.319 \mathrm{mmol}, 1.1$ equiv) and three drops of dry DMF at $0{ }^{\circ} \mathrm{C}$. After the gas evolution ceased and the reaction mixture turned into a clear solution, it was stirred for $0.5 \mathrm{~h}$ at r.t.. Then, a solution of thiophen-2-ylmethanamine $(32.8 \mathrm{mg}, 0.290 \mathrm{mmol}, 1.0$ equiv) in DCM $(0.5 \mathrm{~mL})$ and DIPEA $(0.101 \mathrm{~mL}, 0.580 \mathrm{mmol}$, 2.0 equiv) were added and the reaction mixture was stirred for 16 $\mathrm{h}$ at r.t. The reaction mixture was quenched by adding a small amount of silica gel and concentrating to dryness. The crude product was purified by flash chromatography (12 $\mathrm{g} \mathrm{SiO}_{2}$, gradient: $0 \%$ to $30 \%$ EtOAc in CyHex) affording $66 \mathrm{mg}(0.203$ mmol, $70 \%$ ) of a brown solid. Single crystals were obtained by vapor diffusion using $\mathrm{CH}_{2} \mathrm{Cl}_{2}$ (solvent) and pentane (antisolvent).

${ }^{1} \mathrm{H}$ NMR $\left(500 \mathrm{MHz}, \mathrm{CDCl}_{3}\right) \delta=7.25-7.28(\mathrm{~m}, 1 \mathrm{H}), 7.06(\mathrm{~m}$, $1 \mathrm{H}), 6.99$ (dd, J = 5.3, $3.5 \mathrm{~Hz}, 1 \mathrm{H}$ ), 5.98 (br. s., $1 \mathrm{H}$ ), 4.76 (d, J $=5.8 \mathrm{~Hz}, 2 \mathrm{H}), 4.64-4.71(\mathrm{~m}, 2 \mathrm{H}), 4.33-4.39(\mathrm{~m}, 2 \mathrm{H}), 4.19(\mathrm{~s}$, $5 \mathrm{H}) ;{ }^{13} \mathrm{C} \mathrm{NMR}\left(126 \mathrm{MHz}, \mathrm{CDCl}_{3}\right) \delta 170.3,141.7,127.0,126.0$, 125.2, 75.7, 70.7 (2C), 69.8 (5C), 68.3 (2C), 38.4; M.p.: 139-141 ${ }^{\circ} \mathrm{C}$; HRMS-ESI: calculated for $\mathrm{C}_{16} \mathrm{H}_{15} \mathrm{FeNNaOS}[\mathrm{M}+\mathrm{Na}]^{+}$: 348.0116; found: 348.0123 . 
5.9. $N$-((1R,2S)-1-hydroxy-1-phenylpropan-2-yl)-N-ferrocenyl amide $8 \mathrm{c}$

To a suspension of ferrocenecarboxylic acid (49 mg, 0.212 mmol, 1.0 equiv), (-)-ephedrine ( $35 \mathrm{mg}, 0.212 \mathrm{mmol}, 1.0$ equiv), and DIPEA ( $0.12 \mathrm{~mL}, 0.424 \mathrm{mmol}, 2.0$ equiv) in DCM $(2 \mathrm{~mL})$ was added PyBOP (110 mg, $0.212 \mathrm{mmol}, 1.0$ equiv). The reactions mixture turns into an orange solution and was stirred at $\mathrm{rt}$ for $16 \mathrm{~h}$. The reaction mixture was quenched with brine, diluted with EtOAc and the phases were separated. The aq. layer was extracted with EtOAc twice and the combined org. extracts were concentrated under reduced pressure. The crude product was purified by flash chromatography $\left(12 \mathrm{~g} \mathrm{SiO}_{2}\right.$, gradient: $0 \%$ to $50 \%$ EtOAc in CyHex) affording $68 \mathrm{mg}(0.180 \mathrm{mmol}, 85 \%)$ of an orange solid. Single crystals were obtained by vapor diffusion using THF (solvent) and cyclohexane (anti-solvent). Due to the presence of conformers, the NMR analysis had to be carried out at 393 Kelvin. Due the conformational effects, some ${ }^{13} \mathrm{C}-\mathrm{NMR}$ signals contain shoulders, others are of weak intensity.

${ }^{1} \mathrm{H}$ NMR (500 MHz, DMSO- $\left.d_{6}, 393 \mathrm{~K}\right) \delta 7.32$ (m, $\left.4 \mathrm{H}\right), 7.24$ $(\mathrm{m}, 1 \mathrm{H}), 5.02(\mathrm{~d}, \mathrm{~J}=4.3 \mathrm{~Hz}, 1 \mathrm{H}), 4.71(\mathrm{~m}, 1 \mathrm{H}), 4.50(\mathrm{~m}, 1 \mathrm{H})$, 4.45 (br. s., $1 \mathrm{H}$ ), 4.40 (br. s., $1 \mathrm{H}$ ), 4.28 (br. s., $2 \mathrm{H}$ ), 4.12 (s, 5 $\mathrm{H}), 2.95$ (s, $3 \mathrm{H}), 1.24$ (d, J = 6.7 Hz, $3 \mathrm{H}) ;{ }^{13} \mathrm{C} \mathrm{NMR} \mathrm{(126} \mathrm{MHz,}$ DMSO- $\left.d_{6}, 393 \mathrm{~K}\right) \delta 168.7,143.1,127.0,126.2,125.8,79.6,74.4$, 70.0, 68.7, 67.9, 56.2, 31.0, 12.3; M.p.: $140-141^{\circ} \mathrm{C}$; HRMS-ESI: calculated for $\mathrm{C}_{21} \mathrm{H}_{24} \mathrm{FeNO}_{2}[\mathrm{M}+\mathrm{H}]^{+}: 378.1151$; found: 378.1157 ; $[\mathrm{a}]_{\mathrm{D}}{ }^{26}=-89.4\left(c 1.0, \mathrm{CHCl}_{3}\right)$.

\section{Acknowledgements}

This work was supported by the European Research Council (Advanced Grant No. 321066 to A. M. E.). We thank Imma Escofet (ICIQ) for determining optical rotations and for additional experiments. Guillaume Pilet and Markus Neuburger are gratefully acknowledged for providing X-ray structure factors of $8 \mathbf{a}, 7 \mathbf{a}-\mathbf{b}$ and $\mathbf{8 d - 8 e}$, respectively.

\section{References}

(1) Nicolaou, K. C.; Snyder, S. A. Angew. Chem. Int. Ed. 2005, 44, 1012-1044.

(2) Maier, M. E. Nat. Prod. Rep. 2009, 26, 1105-1124.

(3) Molinski, T. F.; Morinaka, B. I. Tetrahedron 2012, 68 , 9307-9343.

(4) Kong, L.-Y.; Wang, P. Chin. J. Nat. Med. 2013, 11, 193-

198.

(5) Harada, N. Chirality 2008, 20, 691-723.

(6) Seco, J. M.; Quiñoá, E.; Riguera, R. Chem. Rev. 2004, 104, $17-118$.

(7) Seco, J. M.; Quiñoá, E.; Riguera, R. Chem. Rev. 2012, 112, 4603-4641.

(8) Batista Jr, J. M.; Blanch, E. W.; Bolzani, V. d. S. Nat.

Prod. Rep. 2015, 32, 1280-1302.

(9) Thompson, A. L.; Watkin, D. J. Tetrahedron: Asymmetry 2009, 20, 712-717.

(10) Deschamps, J. R. Life Sci. 2010, 86, 585-589.

(11) Flack, H. Acta Crystallogr., Sect. A 1983, 39, 876-881.

(12) Flack, H. D.; Bernardinelli, G. Acta Crystallogr., Sect. A 1999, 55, 908-915.

(13) Flack, H. D.; Bernardinelli, G. J. Appl. Crystallogr. 2000, 33, 1143-1148.

(14) Flack, H. D.; Bernardinelli, G. Chirality 2008, 20, 681-

690

(15) Hooft, R. W. W.; Straver, L. H.; Spek, A. L. J. Appl.

Crystallogr. 2008, 41, 96-103.

(16) Parsons, S.; Flack, H. D.; Wagner, T. Acta Crystallogr.,

Sect. B 2013, 69, 249-259.
(17) Escudero-Adan, E. C.; Benet-Buchholz, J.; Ballester, P. Acta Crystallogr., Sect. B 2014, 70, 660-668.

(18) Spingler, B.; Schnidrig, S.; Todorova, T.; Wild, F.

CrystEngComm 2012, 14, 751-757.

(19) Inokuma, Y.; Yoshioka, S.; Ariyoshi, J.; Arai, T.; Hitora, Y.; Takada, K.; Matsunaga, S.; Rissanen, K.; Fujita, M. Nature 2013, 495, 461-466; corrigendum: Nature 2013, 501, 262-262.

(20) Ramadhar, T. R.; Zheng, S.-L.; Chen, Y.-S.; Clardy, J. Acta Crystallogr., Sect. A 2015, 71, 46-58.

(21) Hoshino, M.; Khutia, A.; Xing, H.; Inokuma, Y.; Fujita, M. IUCrJ 2016, 3, 139-151.

(22) Urban, S.; Brkljača, R.; Hoshino, M.; Lee, S.; Fujita, M. Angew. Chem. Int. Ed. 2016, 55, 2678-2682.

(23) Matsuda, Y.; Mitsuhashi, T.; Lee, S.; Hoshino, M.; Mori, T.; Okada, M.; Zhang, H.; Hayashi, F.; Fujita, M.; Abe, I. Angew. Chem. Int. Ed. 2016, 55, 5785-5788.

(24) Brady, O. L.; Elsmie, G. V. Analyst 1926, 51, 77-78.

(25) Allen, C. F. H. J. Am. Chem. Soc. 1930, 52, 2955-2959.

(26) Hudson, C. S. J. Chem. Educ. 1941, 18, 353.

(27) Lichtenthaler, F. W. Angew. Chem. Int. Ed. Engl. 1992, 31, 1541-1556.

(28) Fischer, E. Ber. Dtsch. Chem. Ges. 1884, 17, 579-584.

(29) Fischer, E. Ber. Dtsch. Chem. Ges. 1891, 24, 1836-1845.

(30) Parker, G. L.; Smith, L. K.; Baxendale, I. R. Tetrahedron 2016, 72, 1645-1652.

(31) Hamano, S. Bull. Agr. Chem. Soc. Japan 1935, 11, 148-

153

(32) Isler, O.; Huber, W.; Ronco, A.; Kofler, M. Helv. Chim. Acta 1947, 30, 1911-1927.

(33) Baxter, J. G.; Robeson, C. D. Science 1940, 92, 203-204.

(34) Table of derivatives can still be found in text- and handbooks: (a) Rappoport, Z. CRC handbook of tables for organic compound identification; 3rd ed.; CRC Press, Inc.: Boca Raton, Florida, 1967; (b) Vogel, A. I.; Tatchell, A. R.; Furnis, B. S.; Hannaford, A. J.; Smith, P. W. G. Vogel's Textbook of Practical Organic Chemistry; 5th ed.; Longman: Essex, 1989; (c) Jerry R. Mohrig; Hammond, C. N.; Schatz, P. F. Techniques in Organic Chemistry; 2nd ed.; W. H. Freeman and Company: New York, 2006. (35) The CSD counts 625 entries for 4-nitrobenzoates and 167 entries for 4-nitrobenzamides.

(35) The CSD counts 625 entries for 4-nitrobenzoates and 167 entries for 4-nitrobenzamides.

(36) Van Berkel, G. J.; Quirke, J. M. E.; Tigani, R. A.; Dilley, A. S.; Covey, T. R. Anal. Chem. 1998, 70, 1544-1554.

(37) Quirke, J. M. E.; Hsu, Y.-L.; Van Berkel, G. J. J. Nat. Prod. 2000, 63, 230-237.

(38) Quirke, J. M. E.; Van Berkel, G. J. J. Mass Spectrom. 2001, 36, 179-187.

(39) Witte, P.; Lal, T. K.; Waymouth, R. M. Organometallics 1999, 18, 4147-4155.

(40) Shibata, T.; Arai, Y.; Takami, K.; Tsuchikama, K.; Fujimoto, T.; Takebayashi, S.; Takagi, K. Adv. Synth. Catal. 2006, 348, 2475-2483.

(41) Shibata, T.; Iwahashi, K.; Kawasaki, T.; Soai, K. Tetrahedron: Asymmetry 2007, 18, 1759-1762.

(42) Shibata, T.; Nishizawa, G.; Endo, K. Synlett 2008, 2008, 765-768.

(43) Holstein, P. M.; Vogler, M.; Larini, P.; Pilet, G.; Clot, E.; Baudoin, O. ACS Catal. 2015, 5, 4300-4308.

(44) Holstein, P. M. Ph.D. Thesis, Université Claude Bernard Lyon 1, 2014.

(45) Dailler, D.; Danoun, G.; Baudoin, O. Angew. Chem. Int. Ed. 2015, 54, 4919-4922.

(46) Dailler, D.; Danoun, G.; Ourri, B.; Baudoin, O. Chem. Eur. J. 2015, 21, 9370-9379.

(47) Petit, L.; Banwell, M. G.; Willis, A. C. Org. Lett. 2011, 13, 5800-5803.

(48) For further details, see the supporting informations.

(49) Hoffmann, K.; Rießelmann, B.; Wenzel, M. Liebigs Ann.

Chem. 1980, 1980, 1181-1185. 
(50) Deschenaux, R.; Marendaz, J.-L.; Santiago, J.; Goodby, J. W. Helv. Chim. Acta 1995, 78, 1215-1218.

(51) Medina, J. C.; Gay, I.; Chen, Z.; Echegoyen, L.; Gokel, G. W. J. Am. Chem. Soc. 1991, 113, 365-366.

(52) related menthol esters were accessed by esterification of cyclopentadienyl carboxylic acid followed by complexation of a metal ion: Uno, M.; Ando, K.; Komatsuzaki, N.; Takahashi, S. J. Chem. Soc., Chem. Commun. 1992, 964-965.

(53) Stoll, A. H.; Mayer, P.; Knochel, P. Organometallics 2007, 26, 6694-6697.

(54) Yang, L.; Melot, R.; Neuburger, M.; Baudoin, O. Chem. Sci. 2017, 8, 1344-1349.

(55) Bucher, C.; Deans, R. M.; Burns, N. Z. J. Am. Chem. Soc. 2015, 137, 12784-12787.

(56) Landry, M. L.; Hu, D. X.; McKenna, G. M.; Burns, N. Z. J. Am. Chem. Soc. 2016, 138, 5150-5158.

(57) You, W.; Brown, M. K. J. Am. Chem. Soc. 2015, 137, 14578-14581.

(58) Hugelshofer, C. L.; Magauer, T. Chem. Eur. J. 2016, 22, 15125-15136.

(59) Speck, K.; Wildermuth, R.; Magauer, T. Angew. Chem. Int. Ed. 2016, 55, 14131-14135.

(60) Sheldrick, G. Acta Crystallogr., Sect. C 2015, 71, 3-8.

(61) Thompson, A. L.; Watkin, D. J. J. Appl. Crystallogr. 2011, 44, 1017-1022.

(62) Kojima, T.; Noguchi, D.; Nakayama, T.; Inagaki, Y.; Shiota, Y.; Yoshizawa, K.; Ohkubo, K.; Fukuzumi, S. Inorg. Chem. 2008, 47, 886-895.

(63) Mohottalage, S.; Tabacchi, R.; Guerin, P. M. Flavour Fragr. J. 2007, 22, 130-138. 